\title{
Ornamental Palms for Central Florida ${ }^{1}$
}

\author{
Timothy K. Broschat and James E. Davis ${ }^{2}$
}

Palms are often thought of as symbols of the tropics, but fortunately there are a number of palm species that grow in warm, temperate climates, such as that of Central Florida. Palms offer bold-textured foliage and characteristic growth forms that no other plant group can provide. Palms may have feather-like leaves (pinnate) or fan-shaped leaves (palmate) on slender to thick trunks. They may be single or multistemmed (clumping) and range in height from a couple of feet to more than 100 feet.

When choosing a palm for a particular site, keep in mind the species' ultimate size in terms of both height and spread. Are there overhead power lines nearby that the palm will eventually grow into? Will a tall species eventually look out of place next to a single-story house? Is there sufficient space to accommodate potentially large leaves or the broad spread of some clumping species? If the property is close to the seashore, keep in mind that only a few species tolerate salt spray on their foliage, and even fewer tolerate brackish water on their roots.

\section{Planting Palms}

When planting palms, avoid sites with very high water tables unless you can build up the site with a sand berm on which to plant. Dig a hole the same depth as the root ball but about twice the diameter. Place the palm in the hole and refill the hole with the soil that was removed from it. Research has shown no benefits from amending the backfill with organic matter (peat, etc.) or any other material. Do not worry about any tightly wrapped roots in container-grown palms. Although wrapping roots can cause serious problems for broad-leaved trees and shrubs, wrapped palm roots will eventually be replaced by larger, straight roots from the base of the palm trunk. A properly planted palm should have about 1 inch of soil covering the top of the root ball. Large field-grown palms require specialized heavy equipment and are best installed by professional landscapers.

Container-grown palms benefit from fertilization with a good controlled-release, container-type fertilizer (an analysis of 18-6-12 or similar would be appropriate) applied to the soil surface over the planting hole during the first 6 months after planting. Field-grown palms may also be fertilized, but with a landscape palm fertilizer having an analysis of $8-2-12-4 \mathrm{Mg}$. This landscape fertilizer should also be used on container-grown palms after the first 6 months.

In order to retain water in the vicinity of the root ball, it is recommended to construct a shallow (6-8 inches high) berm with soil just outside the perimeter of the planting hole. The amount of water to be applied and the frequency of its application depend on the soil type, temperature, humidity, wind speed, light intensity, and other conditions. The point is to apply enough water that it penetrates down to the bottom of the root ball. It should be repeated when the soil about 2 inches down begins to dry. The root ball should never be allowed to completely dry out until the palm becomes well established. For most species, that will generally be about 12 months after transplanting. Any bracing installed for support can be removed at that time.

1. This document is ENH-60, one of a series of the Environmental Horticulture Department, Florida Cooperative Extension Service, Institute of Food and Agricultural Sciences, University of Florida. Original publication date June 1997. Revised January 2013. Visit the EDIS website at http://edis.ifas.ufl.edu.

2. Timothy K. Broschat, professor, Fort Lauderdale Research and Education Center, and James E. Davis, Extension agent, Sumter County. University of Florida Institute of Food and Agricultural Sciences, Gainesville, FL 32611.

The Institute of Food and Agricultural Sciences (IFAS) is an Equal Opportunity Institution authorized to provide research, educational information and other services only to individuals and institutions that function with non-discrimination with respect to race, creed, color, religion, age, disability, sex, sexual orientation, marital status, national origin, political opinions or affiliations. U.S. Department of Agriculture, Cooperative Extension Service, University of Florida, IFAS, Florida A\&M University Cooperative Extension Program, and Boards of County Commissioners Cooperating. Nick T. Place, Dean 
For more information about transplanting palms, see Transplanting Palms in the Landscape (http://edis.ifas.ufl. edu/ep001).

\section{Palm Maintenance}

Once established, palm maintenance is fairly simple. Completely dead leaves need to be removed if they do not fall off by themselves. However, avoid removing discolored or partially dead older leaves as these are symptoms of potassium deficiency (http://edis.ifas.ufl.edu/ep269); removing them removes a supplemental source of potassium for the palms growing in potassium-deficient soils (all soils in Central Florida are potassium deficient for palms). For more information, see Pruning Palms (http://edis.ifas. ufl.edu/ep443).

After a year of establishment, most palms do not require supplemental irrigation except under severe drought conditions. However, they do benefit from regular fertilization with a slow-release palm fertilizer having an analysis of $8-2-12-4 \mathrm{Mg}$ or $8-0-12-4 \mathrm{Mg}$. For more information about fertilizing palms in the landscape, refer to Fertilization of Field-Grown and Landscape Palms in Florida (http://edis. ifas.ufl.edu/ep261).

\section{Palm Problems}

Most palms are susceptible to one or more problems that may be important when selecting a particular species. For example, Canary Island date palms (http://edis.ifas.ufl. edu/pp139), queen palms, and Mexican fan palms (http:// edis.ifas.ufl.edu/pp278) are highly susceptible to a lethal disease called Fusarium wilt. Date palms, such as Phoenix dactylifera (edible date) and P. sylvestris (wild date), and cabbage palms (Sabal palmetto) are highly susceptible to Texas Phoenix palm decline (http://edis.ifas.ufl.edu/pp163), a Central Florida relative of lethal yellowing (http://edis. ifas.ufl.edu/pp146), a disease that does not occur in Central Florida. On the other hand, all palms are susceptible to trunk rot diseases, such as Ganoderma butt rot (http://edis. ifas.ufl.edu/pp100) and Thielaviopsis trunk rot (http://edis. ifas.ufl.edu/pp143), so there are no species resistant to these diseases from which to select. Planting a wide variety of palm species or mixing palms with hardwood trees helps reduce the chances for a disease epidemic. All palms are susceptible to nutritional deficiencies (http://edis.ifas.ufl. edu/ep273), physiological disorders (http://edis.ifas.ufl.edu/ ep263), and insect pests, but most of these problems are treatable. Finally, when growing palms in less than tropical climates, cold injury is a common recurring problem. For more information, please refer to Cold Damage on Palms (http://edis.ifas.ufl.edu/mg318).

\section{Palm Species}

Table 1 provides a list of palm species that generally grow well in Central Florida. While other species, including foxtail palm (Wodyetia bifurcata), pygmy date palm (Phoenix roebelenii), triangle palm (Dypsis decaryi), and Alexandra palm (Archonotophoenix alexandrae), are sometimes marketed in Central Florida and may survive with damage in some protected locations, they are not reliably hardy in most of the region. 
Table 1. Selected Palms for Central Florida

\begin{tabular}{|c|c|c|c|c|c|c|c|}
\hline Species & $\begin{array}{l}\text { Common } \\
\text { name }\end{array}$ & $\begin{array}{l}\text { Leaf } \\
\text { type }\end{array}$ & $\begin{array}{l}\text { Typical size } \\
(\mathrm{H} \times \mathrm{W})\end{array}$ & Zone* & $\begin{array}{l}\text { Clumping/ } \\
\text { single stem? }\end{array}$ & $\begin{array}{l}\text { Salt spray } \\
\text { tolerance }\end{array}$ & Comments \\
\hline $\begin{array}{l}\text { Acoelorrhaphe } \\
\text { wrightii }\end{array}$ & $\begin{array}{l}\text { Paurotis } \\
\text { palm }\end{array}$ & Fan & $20 \times 20 \mathrm{ft}$ & $9 a$ & Clumping & Moderate & $\begin{array}{l}\text { Poorly adapted } \\
\text { to alkaline soils; } \\
\text { petioles spiny }\end{array}$ \\
\hline $\begin{array}{l}\text { Allagoptera } \\
\text { arenaria }\end{array}$ & $\begin{array}{l}\text { Seashore } \\
\text { palm }\end{array}$ & Feather & $5 \times 8 \mathrm{ft}$ & $9 b$ & Clumping & High & $\begin{array}{l}\text { Shrubby palm } \\
\text { with blue-green } \\
\text { foliage; good for } \\
\text { coastal sites }\end{array}$ \\
\hline Arenga engleri & $\begin{array}{l}\text { Dwarf } \\
\text { sugar palm }\end{array}$ & Feather & $10 \times 15 \mathrm{ft}$ & $9 b$ & Clumping & Low & $\begin{array}{l}\text { Individual stems } \\
\text { die after fruiting }\end{array}$ \\
\hline $\begin{array}{l}\text { Bismarckia } \\
\text { nobilis }\end{array}$ & $\begin{array}{l}\text { Bismarck } \\
\text { palm }\end{array}$ & Fan & $30 \times 20 \mathrm{ft}$ & $9 b ?$ & Single stem & Moderate & $\begin{array}{l}\text { Marginally hardy } \\
\text { in Central Florida; } \\
\text { silver and green } \\
\text { forms exist; less } \\
\text { wind resistant } \\
\text { than most species }\end{array}$ \\
\hline Butia capitata & Pindo palm & Feather & $15 \times 12 \mathrm{ft}$ & $8 a$ & Single stem & Low & $\begin{array}{l}\text { Edible fruit; slow } \\
\text { growing but } \\
\text { extremely hardy }\end{array}$ \\
\hline $\begin{array}{l}\text { X Butiagrus } \\
\text { nabonnandii }\end{array}$ & Mule palm & Feather & $25 \times 20 \mathrm{ft}$ & $8 a$ & Single stem & Low & $\begin{array}{l}\text { Slow growing; } \\
\text { variable in size } \\
\text { and form }\end{array}$ \\
\hline
\end{tabular}


Archival copy: for current recommendations see http://edis.ifas.ufl.edu or your local extension office.

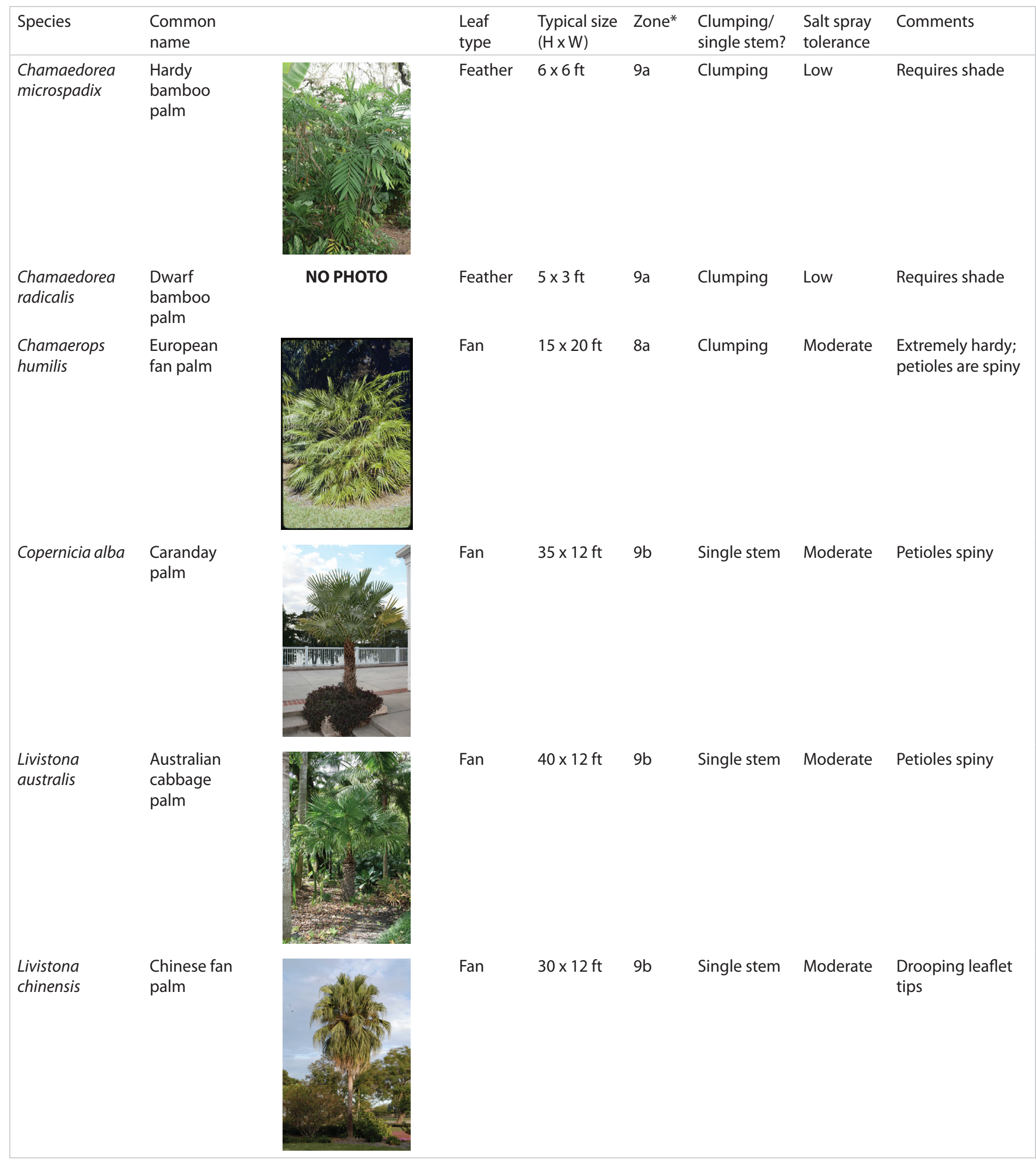




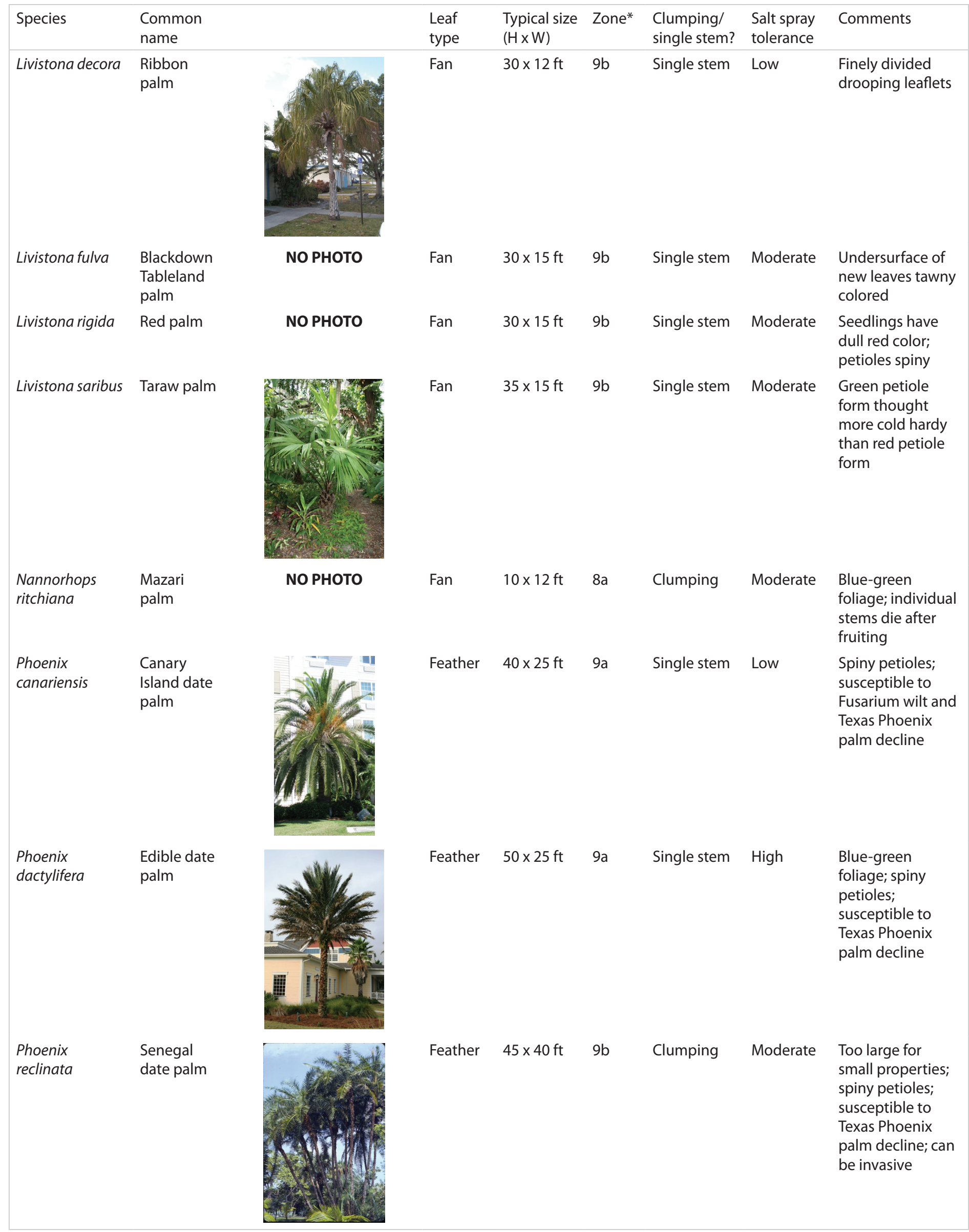




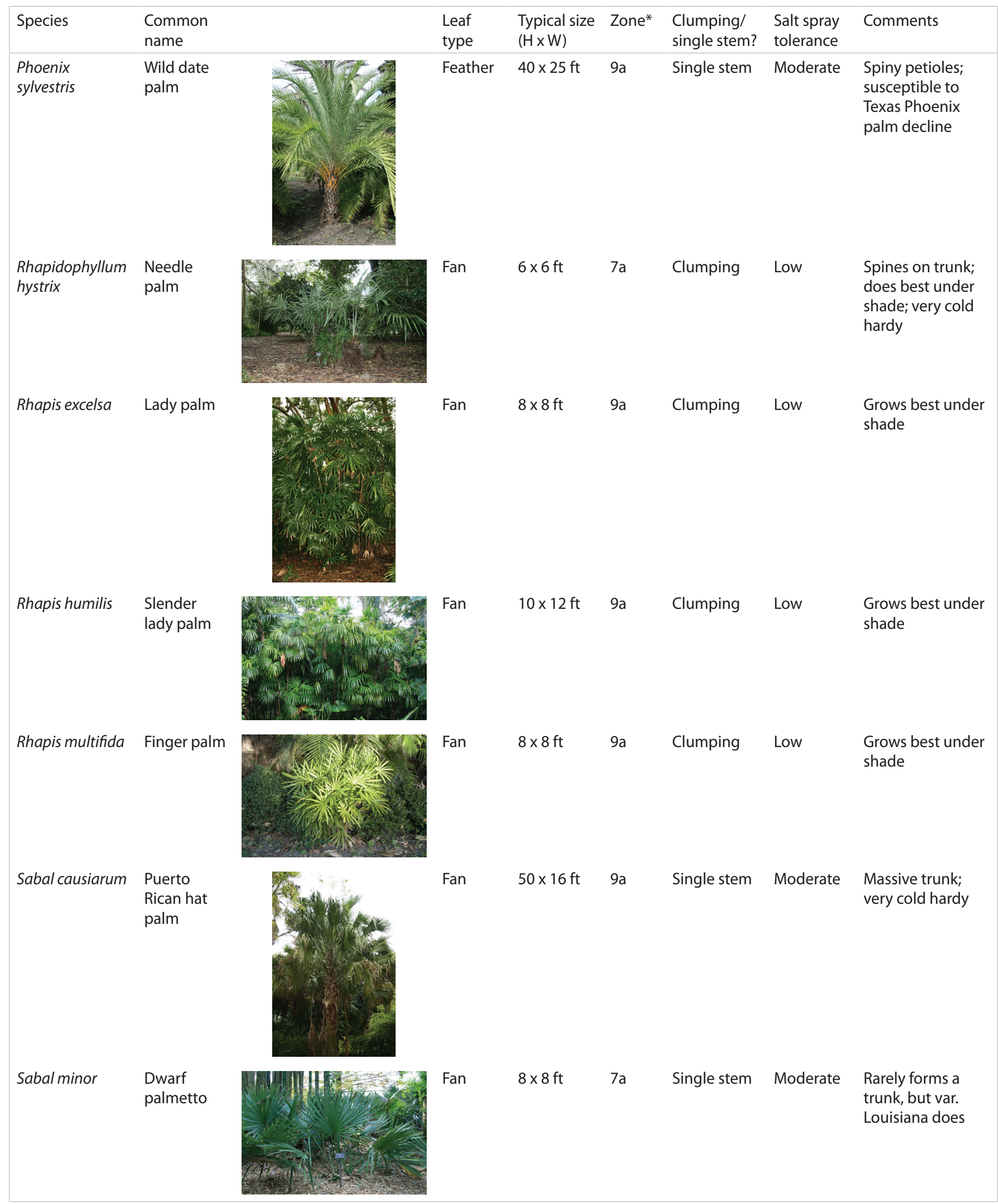




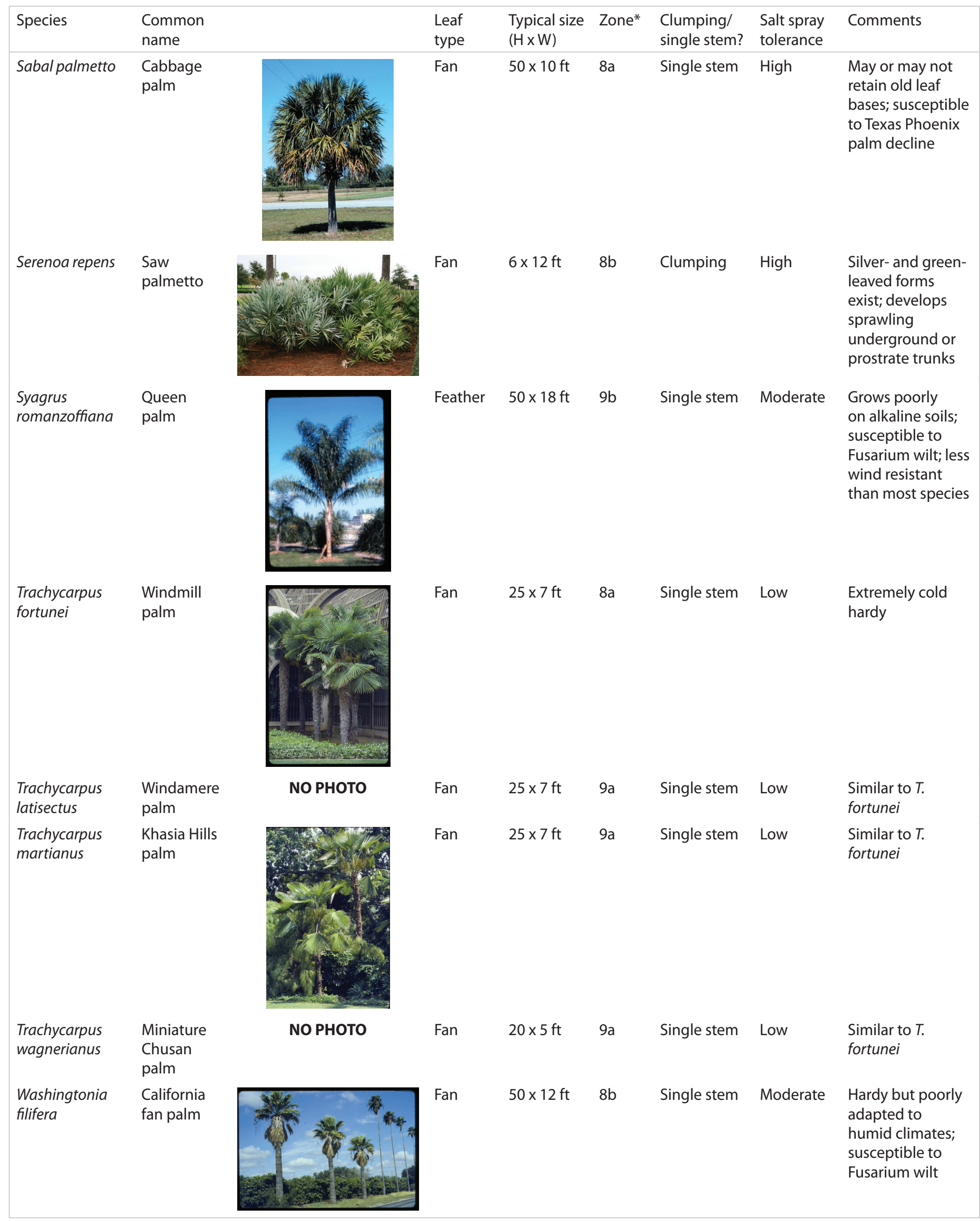


Archival copy: for current recommendations see http://edis.ifas.ufl.edu or your local extension office.

\begin{tabular}{|c|c|c|c|c|c|c|c|c|}
\hline Species & $\begin{array}{l}\text { Common } \\
\text { name }\end{array}$ & & $\begin{array}{l}\text { Leaf } \\
\text { type }\end{array}$ & $\begin{array}{l}\text { Typical size } \\
(\mathrm{H} \times \mathrm{W})\end{array}$ & Zone* & $\begin{array}{l}\text { Clumping/ } \\
\text { single stem? }\end{array}$ & $\begin{array}{l}\text { Salt spray } \\
\text { tolerance }\end{array}$ & Comments \\
\hline $\begin{array}{l}\text { Washingtonia } \\
\text { robusta }\end{array}$ & $\begin{array}{l}\text { Mexican } \\
\text { fan palm }\end{array}$ & 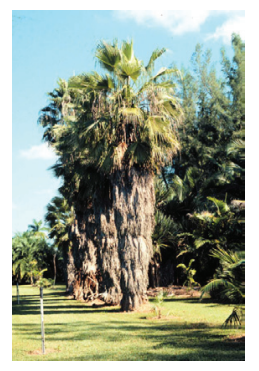 & Fan & $80 \times 10 \mathrm{ft}$ & $9 a$ & Single stem & Moderate & $\begin{array}{l}\text { Grows too tall } \\
\text { for residential } \\
\text { landscapes; } \\
\text { susceptible to } \\
\text { Fusarium wilt; fast } \\
\text { growing, but not } \\
\text { as wind resistant } \\
\text { as other species }\end{array}$ \\
\hline
\end{tabular}

Credits: T. K. Broschat and J. E. Davis 